\title{
Review Article \\ Cumulative Impacts of Human Interventions and Climate Change on Mangrove Ecosystems of South and Southeast Asia: An Overview
}

\author{
Rajarshi DasGupta and Rajib Shaw \\ Graduate School of Global Environmental Studies, Kyoto University, Yoshida Honmachi, Sakyo-ku, Kyoto 606-8501, Japan
}

Correspondence should be addressed to Rajarshi DasGupta; rajarshidg1@yahoo.co.in

Received 30 November 2012; Revised 6 February 2013; Accepted 14 March 2013

Academic Editor: Felipe Garcia-Rodriguez

Copyright (C) 2013 R. DasGupta and R. Shaw. This is an open access article distributed under the Creative Commons Attribution License, which permits unrestricted use, distribution, and reproduction in any medium, provided the original work is properly cited.

\begin{abstract}
The paper provides an insight into the chronological extinction of the Indo-Malayan mangroves along the South and Southeast Asian coast and categorizes several area-specific anthropogenic and climatic factors that triggered the annihilation of 1.9 million ha of diverse mangroves. On a regional scale, coastal agricultural land development and shrimp farming were identified as major factors accounting for $90 \%$ of the reported loss. The paper also focuses on the existing mangrove management framework of nine developing countries of this region and conducts a comparative analysis of the prevailing legislative arrangement for mangrove management. In general, weak enforcements of legal measures and improper monitoring have been identified as major drawbacks in conservation and restoration initiatives. On the other hand, this paper strongly encourages the prospects of communitybased mangrove management (CBMM) and provides good examples from the ecoregion through comparative case studies. Finally, it concludes with recommendations that outline a suitable mangrove management strategy involving more community empowerment, legalization and mainstreaming of comanagement initiatives, inclusive benefit sharing, and regional cooperation for transboundary ecosystem management.
\end{abstract}

\section{Introduction}

Mangrove forests, still abundant in South and Southeast Asia, are amongst the world's most fragile ecosystems and continue to disappear under the increased threat of climate change and human interventions. Researchers from all over the world agree on the fact that the existence of mangroves forests is under great risk due to fragmentation of the habitats. Moreover, ecosystem services offered by the mangroves are likely to be lost completely within the next 100 years [1] Globally, mangroves are disappearing at an alarming rate of 1 to $2 \%$ per year, faster than the adjacent coral reefs or tropical rainforests [1-3]. Deforestation led by increasing demand for land and climate change events such as rise of sea level and reduction in freshwater flow are considered as major players behind the continuous annihilation of mangroves; however, climate change events may impact to only $10-15 \%$ reduction of mangrove habitats in distant future, whereas the immediate threat comes from uncontrolled exploitation and deforestation [3]. The consequent impacts of such losses resulted in serious concern amongst conservationists and exposed the coastal communities to a further increased threat of climate change and hydrometeorological disasters.

Large stretches of the subtropical and tropical coastlines of South and Southeast Asia are endowed with highly productive mangrove forests. Biogeographically classified as IndoMalayan mangroves, these mangroves are considered as the oldest and most diverse mangrove habitats in existence. As of 2010, it extends over 6.13 million ha and accounts for nearly $40.4 \%$ of global mangroves [4]. Yet, Indo-Malayan mangroves have recorded the highest loss in the last few decades [5]. In general, mangroves of this region are threatened by increasing demand for land, unsustainable production of fish and prawns, mixing of waste water effluents, as well as changing hydroclimatic scenario. Since the entire ecozone is fragmented by political boundaries of several developing nations, the pattern of mangrove exploitation differs significantly under diverse economic priorities. Similarly, restoration and conservation initiatives vary extensively under the different 
socioeconomic, demographic, and political scenario of the respective country. Following the Indian Ocean Tsunami in 2004, initiatives for mangrove conservation and restoration gained popularity; however, it is highly imperative to identify the key drivers of mangrove delineation and the complex mechanisms of community-environment interactions in order to plan and implement a successful restoration strategy. Against this backdrop, this paper examines contemporary country-specific literatures in order to analyze the major delineating factors and their potential impacts. On the other hand, it identifies the achievements and challenges of mangrove conservation and restoration initiatives among several developing nations of South and Southeast Asia through comparative analysis of existing mangrove management framework. Finally, this paper concludes with an appropriate mangrove management strategy in order to regain the valuable ecological and environmental services of Indo-Malayan mangroves.

\section{Biogeographical Distribution of Indo-Malayan Mangroves}

The Indo-Malayan mangroves occur in stretches in the southern coast of Asia, throughout the Indian subcontinent, in almost all the Southeast Asian countries and on the islands in the Indian Ocean, Bay of Bengal, South China Sea, and the North Pacific Ocean. It extends over at least twelve developing countries of the region. Out of its global share of $40.4 \%$, Indonesian mangrove alone accounts for $22.6 \%$, whereas Malaysia (3.7\%), Myanmar (Burma) (3.6\%), Bangladesh (3.2\%), India (2.7\%), and Philippines (1.9\%) contribute significantly to this highly fragile ecosystem [6]. Several other South and Southeast Asian countries such as Thailand, Vietnam, Cambodia, Sri Lanka, and Singapore have significant amount of mangroves. On the basis of common ecological and environmental settings, the Indo-Malayan mangroves have been broadly classified into six distinct mangrove ecosystems. However, information on their discrete ecological and environmental settings is still not well documented. A summary of the extent and diversity has been given in Table 1 with a brief discussion in the following paragraphs. The extent of the distribution is also shown in Figure 1.

2.1. Indus River Delta Mangroves. The Indus River Delta mangroves or the Arabian Sea mangroves, to the west of IndoMalayan ecozone, are the only arid mangroves of the entire ecozone. It spread across the Indus delta along the coast of Pakistan and Gujarat (India). Approximately one third of it belongs to the state of Gujarat, India. The Indus River Delta mangroves represent an ecosystem that is highly adaptable to extreme temperature, high salinity levels, and minimal rainfall. Due to the excessive salinity, species diversity of mangroves is essentially poor with distinct dominance of salt tolerant Avicennia marina $[9,10]$. Of late, these mangroves are reported to be adversely affected by massive reduction of freshwater flow in the Indus River.

2.2. Godavari-Krishna Mangroves. Godavari-Krishna mangroves spread discontinuously across the eastern coast of
India, especially in the states of Orissa, Andhra Pradesh and Tamil Nadu. Sufficient freshwater flow by three major rivers, namely, Mahanadi, Godavari, and Krishna along with a favorable terrain forms the basis of this moderately diverse mangrove ecosystem. The mangrove vegetation is also influenced by tidal fluctuations and varied salinity patterns. The Godavari-Krishna mangrove can be broadly classified into three categories as per their isolated geographical occurrences. In the northern fringes of Godavari-Krishna mangroves, the estuarine areas of the Mahanadi, Brahmani, and Baitarani rivers form the Mahanadi Delta mangroves. It receives plenty of freshwater from Mahanadi and its tributaries resulting in high diversity of 32 true mangrove species [11]. Bhitarkanika, better known for the huge population of migratory birds, is the major mangrove habitat in the Mahanadi delta. In the central fringes, mangrove forest in the delta of the Godavari and Krishna forms the largest mangrove in this region. It covers an area of approximately $400 \mathrm{sq} \cdot \mathrm{km}$. However, this particular stretch is not as diverse as the Mahanadi Delta mangroves. Avicennia marina is the dominant species along with 13 other true mangrove species. In the southern section of the ecoregion, Pichavaram mangroves in the backwaters of the Bay of Bengal remain as one of the healthiest mangrove chunk of the entire Indo-Malayan ecoregion. While Avicennia marina and Rhizophora sp. are the dominant species, 11 other true mangrove species are also reported from Pichavaram $[12,13]$.

2.3. Sundarban Mangroves. The Sundarban mangrove forest, to the north-east of the Godavari-Krishna mangrove ecozone, is a part of the delta of River Ganges, Brahmaputra, and Meghna and disproportionately shared by India and Bangladesh. Due to the gentle slope of the coast and the low lying nature of the deltaic islands, tidal water penetrates up to an average distance of $110 \mathrm{~km}$. [14]. It forms the basis of the largest tidal halophytic forest in the world which extends over an area of $25000 \mathrm{sq} \cdot \mathrm{km}$. The entire area of Sundarban experiences a subtropical monsoonal climate with an average annual rainfall of 1600-1800 mm [14, 15]. Heavy freshwater flow from the three major rivers and good amount of monsoonal rain essentially justifies the high species diversity of the mangroves. Even though species diversity and distribution differ in India and Bangladesh, it is reported that approximately 30-36 true mangrove species are observed with dominance of Heritiera fomes and Excoecaria agallocha [15]. The mangroves of Sundarban essentially host a number of critically endangered fauna including the royal Bengal tiger (Panthera Tigris).

2.4. Burmese (Myanmar) Coast Mangroves. The Myanmar Coast mangroves are the combination of estuarine and coastal mangroves adjoining the eastern coast of the Bay of Bengal. It extends over Myanmar, western coast of Thailand and Peninsular Malaysia. At present, the extent of mangrove area in Myanmar is about $4945 \mathrm{sq} \cdot \mathrm{km}$ [6], out of which $46 \%$ is located in Irrawaddy (Ayeyarwady) delta, while the rest are confined in Rakhine (17\%) and Tanintharyi division (37\%) [16]. Twenty-nine true mangrove species are reported from these areas [17]. The western coast of Thailand hosts 
TABLE 1: Environmental and ecological settings of Indo-Malayan mangroves.

\begin{tabular}{|c|c|c|c|c|c|c|}
\hline Category & $\begin{array}{l}\text { Indus River } \\
\text { Delta } \\
\text { (a) }\end{array}$ & $\begin{array}{l}\text { Godavari- } \\
\text { Krishna } \\
\text { mangroves } \\
\text { (b) }\end{array}$ & $\begin{array}{l}\text { Sundarban } \\
\text { mangroves } \\
\text { (c) }\end{array}$ & $\begin{array}{l}\text { Burmese coast } \\
\text { mangroves } \\
\text { (d) }\end{array}$ & $\begin{array}{l}\text { Indochina } \\
\text { mangroves } \\
\text { (e) }\end{array}$ & $\begin{array}{l}\text { Sunda Shelf } \\
\text { mangrove } \\
\text { (f) }\end{array}$ \\
\hline Type & $\begin{array}{l}\text { Backwater } \\
\text { estuarine }\end{array}$ & Deltaic/estuarine & Deltaic & $\begin{array}{l}\text { Deltaic and } \\
\text { coastal }\end{array}$ & Coastal & Coastal \\
\hline Dominance & Transboundary & Domestic & Transboundary & Transboundary & Transboundary & Transboundary \\
\hline Major river(s) & Indus & $\begin{array}{l}\text { (i) Mahanadi } \\
\text { (ii) Godavari } \\
\text { (iii) Krishna }\end{array}$ & $\begin{array}{l}\text { (i) Ganges } \\
\text { (ii) Brahmaputra } \\
\text { (iii) Meghna }\end{array}$ & Ayeyarwady & $\begin{array}{l}\text { (i) Mekong } \\
\text { (ii) Red River }\end{array}$ & Mahakam River \\
\hline Species richness ${ }^{*}$ & 4 & 34 & 36 & 41 & 40 & 43 \\
\hline $\begin{array}{l}\text { Total forest area } \\
(\mathrm{sq} \cdot \mathrm{km})^{* *}\end{array}$ & 6000 (approx) & 7000 (approx) & 25000 (approx) & 3822 (approx) & 26936 (approx) & 40000 (approx) \\
\hline $\begin{array}{l}\text { Mangrove under } \\
\text { protected area } \\
(\mathrm{sq} \cdot \mathrm{km})^{* *}\end{array}$ & 823 & 920 & 2700 & 125 & 820 & 6,530 \\
\hline Occurrence & $\begin{array}{l}\text { Western of India } \\
\text { and eastern } \\
\text { coast of Pakistan }\end{array}$ & $\begin{array}{l}\text { Eastern coast of } \\
\text { India (Orissa to } \\
\text { Tamil Nadu) }\end{array}$ & $\begin{array}{l}\text { (i) Bangladesh } \\
\text { (ii) India }\end{array}$ & $\begin{array}{l}\text { (i) Myanmar } \\
\text { (ii) Thailand } \\
\text { (west coast) } \\
\text { (ii) Peninsular } \\
\text { Malaysia }\end{array}$ & $\begin{array}{l}\text { (i) Thailand } \\
\text { (east coast) } \\
\text { (ii) Cambodia } \\
\text { (iii) Vietnam } \\
\text { (iv) Malaysia } \\
\text { (v) Philippines }\end{array}$ & $\begin{array}{l}\text { (i) Eastern Malaysia } \\
\text { (ii) Indonesia } \\
\text { (iii) Brunei }\end{array}$ \\
\hline Status & $\begin{array}{l}\text { Critically } \\
\text { Degraded and } \\
\text { fragmented }\end{array}$ & Degraded & Degraded & $\begin{array}{l}\text { Critically } \\
\text { degraded }\end{array}$ & $\begin{array}{l}\text { Critically } \\
\text { degraded }\end{array}$ & Degraded \\
\hline
\end{tabular}

* Species Richness varies significantly among different locations in each category. The highest reported species richness is mentioned here ${ }^{* *}$ Figures provide close approximation.

Source: Assimilated by authors from World Wide Fund for Nature Information Database on World Ecoregions [7, 8].

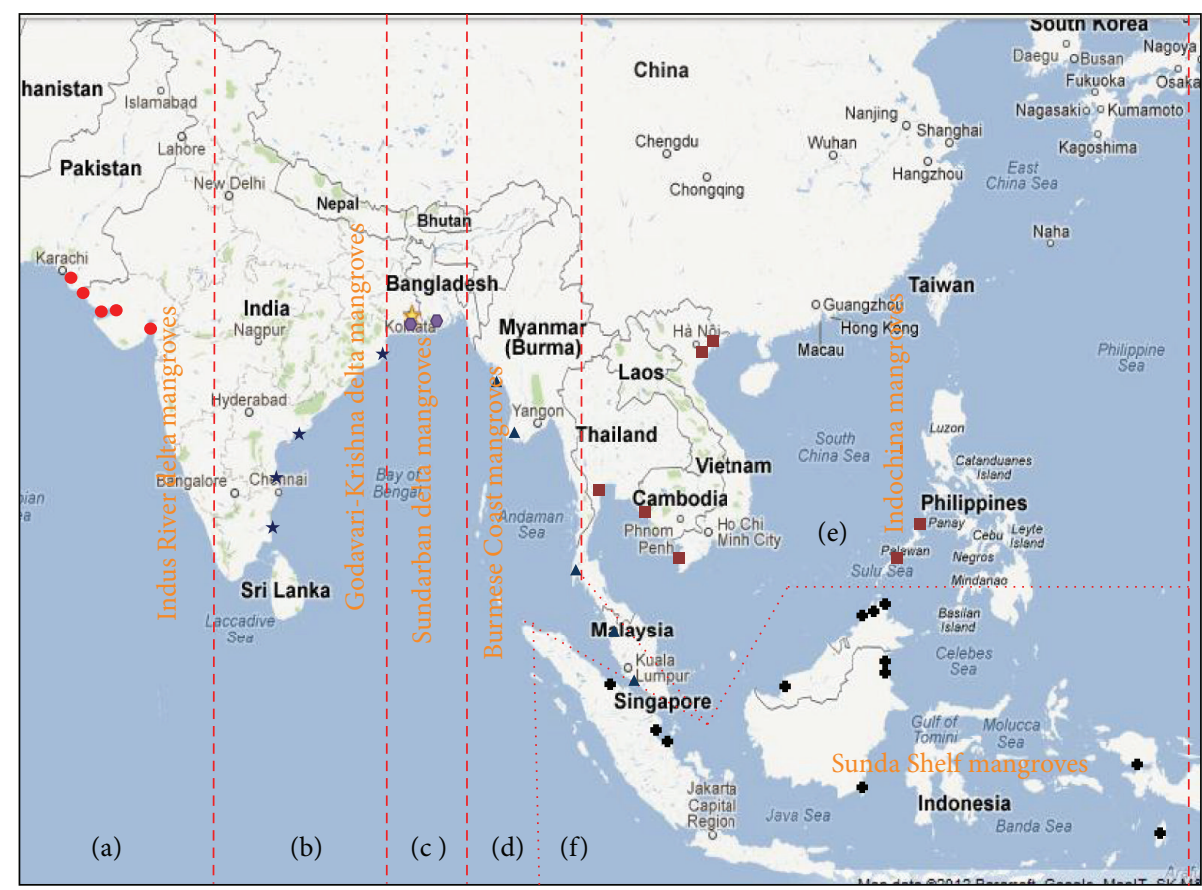

- Arabian Sea mangrove habitats

* Godavari-Krishna mangroves habitats

- Sundarban mangroves habitats
- Burmese Coast mangroves habitats

- Indochina mangroves habitats

- Sunda Shelf mangroves habitats

FIGURE 1: Major mangrove ecosystems in the Indo-Malayan ecozone. (Source: created from google map by the authors.) 
the majority of Thai mangroves. Presently, mangrove in the provinces of Ranong, Phuket, Krabi, Trang, and Satul along the west coast occupies approximately $1458 \mathrm{sq} \cdot \mathrm{km}$ [18]. Similarly, mangroves in Peninsular Malaysia mainly occupy the sheltered west coast close to the Straits of Malacca along the states of Kedah, Perak, Selangor, and Johor. Mangrove reserves of Matang (Perak), South Johor (Johor), and Kelang (Selangor) together constitute 74 percent of the mangrove forest in peninsular Malaysia. All the major near-shore islands, including the Kelang islands in Selangor and Pulau Kukup in Johor, are predominantly colonized by mangroves [19]. The hot and humid climate with high rainfall favors the development of diverse species-rich mangrove habitat. The FAO reported of 41 true mangrove species from the Malaysian coast covering an area of $918 \mathrm{sq} \cdot \mathrm{km}$ [20].

2.5. Indochina Mangroves. The Indochina mangroves are scattered over the eastern coasts of Thailand, Cambodia, Vietnam, and Philippines. They typically occur in the large river deltas and coastal areas that are inundated at high tide but otherwise remain under the freshwater influence. Indochina mangroves are extremely diverse and account for almost $60 \%$ of the mangrove species found in the entire ecozone. Among the large river deltas, Mekong and Red River delta form two major mangrove habitats in the region. The mangroves of Mekong River Delta in the Southwest of Vietnam form the largest stretch of Indochina mangroves. However, much of it was lost during the Vietnam War with a reported reduction of approximately $1000 \mathrm{sq} \cdot \mathrm{km}$ [21]. Presently some $25 \mathrm{sq} \cdot \mathrm{km}$ of dense mangrove exists in the Mekong delta, while the rest remains degraded. Yet, the mangrove species diversity is moderately high with 29 true mangrove species [22]. The Red River delta in the northern coast of Vietnam is the other major mangrove habitat in the region. It is formed by two rivers, namely, the Thai Binh and the Red River. However, the colder climatic conditions, dense human population in the vicinity, and frequent storm surges limit the growth of mangroves. Hence, it has lower species diversity compared to Mekong Delta mangroves. Yet, some typical species are abundant in this region, such as Rhizophora stylosa, Bruguiera gymnorrhiza, and Kandelia candel which are otherwise less encountered in Mekong delta.

In the eastern coast of Thailand, mangroves occur in three different patches surrounding the Gulf of Thailand. The uppermost part is spread over four provinces (Samut Prakan, Samut Sakhon, Samut Songkhram, and a part of Bangkok) covering an area of approximately $273 \mathrm{sq} \cdot \mathrm{km}$. In the south-eastern part, mangroves of five provinces, namely, Trat, Chantaburi, Rayong, Chonburi, and Chachoengsao form another long stretch of $470 \mathrm{sq} \cdot \mathrm{km}$. Along the western side of the Gulf of Thailand, the third mangrove habitat exists over $458 \mathrm{sq} \cdot \mathrm{km}$. Cambodia also had significant amount of mangroves along the Veal Renh and Kompong Som Bays; however, owing to large-scale deforestation, some residual, broken strips of mangroves occur in this area. To the far east of the Indochina ecozone, mangroves in the Philippines are located in the southern fringe of the Filipino archipelago, especially on the Mindanao Island and the western coast of Samar and Palawan province. The province of Palawan hosts the largest mangrove inhabited area covering approximately $562.61 \mathrm{sq} \cdot \mathrm{km}$ of dense mangroves and accounts for $22.23 \%$ of the Filipino mangroves [23]. However, mangroves are found in almost all the coastal provinces of the country. Mangroves of the Philippines are typically diverse; approximately 40 true mangrove species are encountered in clear stratification.

2.6. Sunda Shelf Mangroves. The Sunda Shelf mangroves are found over the island of Borneo, along the fringes of the Riau Archipelago and the east coast of Sumatra. In the Malaysian Borneo, mangrove habitat spreads over the state of Sabah and Sarawak facing the Sulu and Sulawesi Sea. The Sabah mangrove reserve alone accounts for $3174.23 \mathrm{sq} \cdot \mathrm{km}$, while Sarawak has $1320 \mathrm{sq} \cdot \mathrm{km}$ of dense mangrove forest [24]. In case of the Indonesian Borneo (Kalimantan), dense and protected mangrove forest spreads over approximately $1500 \mathrm{sq} \cdot \mathrm{km}$ along the western Kalimantan; however, mangroves in the southern and eastern Kalimantan area, especially in the delta of Mahakam, are rapidly vanishing under anthropogenic stresses. The Indonesian Borneo accounts for only $32 \%$ of the entire Indonesian mangroves, while the rest are confined along the coastal areas of eastern Sumatra islands, Java, Irian Jaya in Papua and in south-eastern Sulawesi. The Irian Jaya covers one of the healthiest and unexplored chunks of mangroves covering $13270 \mathrm{sq} \cdot \mathrm{km}$. The Food and Agricultural Organizations reported about 43 species of true mangroves in Indonesia [20].

\section{Loss of Indo-Malayan Mangroves and Its Potential Consequences}

Information on the chronological country or region specific loss of mangroves is not rigorously documented. In most of the South and Southeast Asian countries, official statistics of mangrove forest is either unavailable or significantly outdated. Meaningful information can only be retrieved through the survey of contemporary scientific literatures. So far, the best initiatives are observed from United Nation's Food and Agricultural Organization (FAO) which documented the global and country wise changes in mangrove cover till 2005. It states that in South and Southeast Asia, mangrove cover has decreased by $25 \%$ from its original extent in 1980, while the Indo-Malayan mangroves suffered a net loss of nearly 1.9 million hectare [20]. More than $90 \%$ of this loss has been registered in Indonesia, Myanmar, Pakistan, Vietnam, Malaysia, and India. It used linear regression analysis to understand the country-specific trend of mangrove loss based on the realistic available information. In order to update this database and examine the present trend, a similar methodology has been adopted in this paper. Recent realistic estimation of mangrove cover has been documented from available literature and official reports. Table 2 summarizes the present extent of mangroves in nine countries of South and Southeast Asia. The assessment year is not uniform for all the mentioned countries; however, priorities were given to document the realistic official estimations from the respective countries. Also, it is important to note that these figures provide a close approximation but do not necessarily reflect the exact ground reality. 
TABLE 2: Country-specific temporal variation of mangrove cover.

\begin{tabular}{|c|c|c|c|c|c|c|c|c|c|}
\hline \multirow{2}{*}{ Country/year } & \multicolumn{9}{|c|}{ Mangrove cover in sq. $\mathrm{km}$} \\
\hline & 1980 & 1990 & $\begin{array}{c}\text { \% Change } \\
(1980-1990)\end{array}$ & 2000 & $\begin{array}{c}\text { \% Change } \\
(1990-2000)\end{array}$ & 2005 & Present & Assessment year & $\begin{array}{l}\text { \% Change } \\
\text { (2000-latest) }\end{array}$ \\
\hline Pakistan & 3450 & 2070 & -40 & 1580 & -23.67 & 1570 & $981.28^{\mathrm{a}}$ & 2010 & -37.89 \\
\hline India & 5067 & 4670 & -7.84 & 4482 & -4.03 & 4480 & $4639^{\mathrm{b}}$ & 2009 & 3.50 \\
\hline Bangladesh & 4280 & 4600 & 7.48 & 4760 & 3.48 & 4760 & $4810^{\mathrm{c}}$ & 2007 & 1.05 \\
\hline Myanmar & 5550 & 5361 & -3.41 & 5167 & -3.62 & 5070 & $4379.21^{\mathrm{d}}$ & 2007 & -15.24 \\
\hline Indonesia & 42000 & 35000 & -16.67 & 31500 & -10 & 29000 & $32440^{\mathrm{e}}$ & 2009 & 2.98 \\
\hline Malaysia & 6740 & 6420 & -4.75 & 5895 & -8.18 & 5650 & $5775^{\mathrm{f}}$ & 2007 & -2.03 \\
\hline Vietnam & 2691.5 & 2135 & -20.68 & 1575 & -26.23 & 1570 & $1597.6^{\mathrm{g}}$ & 2008 & 1.43 \\
\hline Philippines & 2950 & 2730 & -7.46 & 2500 & -8.42 & 2400 & $2091^{\mathrm{h}}$ & 2007 & -16.36 \\
\hline Thailand & 2800 & 2502 & -10.64 & 2441 & -2.44 & 2400 & $2296^{\mathrm{i}}$ & 2007 & -5.94 \\
\hline
\end{tabular}

${ }^{\mathrm{a}}[25],{ }^{\mathrm{b}}[26],{ }^{\mathrm{c}}[27],{ }^{\mathrm{d}}[28],{ }^{\mathrm{e}}[29],{ }^{\mathrm{f}}[24],{ }^{\mathrm{g}}[30],{ }^{\mathrm{h}}[31],{ }^{\mathrm{i}}[32]$.

Analysis of the data presented in Table 2 depicts that since the last decade, India, Indonesia, and Vietnam showed an increasing trend in gross mangrove forest area compared to the massive declining trend observed in the previous two decades. This finding can be referred to substantial achievement in mangrove conservation and restoration in the mentioned countries. Among all the countries, mangroves of Bangladesh remain largely unaffected over the years. On the contrary, Pakistan, Thailand, Myanmar, and Philippines continued to suffer the loss of mangroves. With a disappearing rate of more than $2 \%$ per year, particularly mangroves in Pakistan and Myanmar remain critically threatened.

Potential consequences of the loss of mangroves in this region are multifaceted with distinct ecological, social, and economic dimensions. In many remote coastal areas of this region, mangrove-based livelihood opportunities strongly define the social and economical well-being of the coastal communities. Mangroves are capable of producing a rich natural capital providing enormous economic and environmental services. Over the years, mangroves have sustained more than 70 direct human activities. Of these, on-shore fishing and timber and firewood collection are worth mentioning in the backdrop of South and Southeast Asia, where rural poverty still forms a critical sociopolitical issue. With the advancement of modern petroleum fuels, the dependence on mangrove firewood has reduced significantly; however, on-shore fishing is still widely practiced in different parts of South and Southeast Asia. Degradation of mangroves has adversely impacted traditional fishing activities. Many aquatic species including the commercially important fishes were lost or significantly reduced along with the mangroves. For example, there has been more than $50 \%$ reduction in fish catch in the Indus-Delta since 1993 [33]. Similar examples can also be cited from various parts of India, Thailand, Myanmar, and Philippines. Loss of livelihood insisted coastal fishing communities to work as landless labors or to toil in private aquaculture ponds. As a result, crucial alterations of sociological hierarchy are also observed. Women, who were initially engaged in different mangrove-based livelihood activities, such as fish hunting and wood and firewood collection, now engage themselves in alternative livelihoods far away from their places leading to disintegration and improper upbringing of their families [34].

On the other hand, the indirect services of mangrove forest in terms of shoreline protection, biofiltration, carbon sequestration, and disaster risk reduction are enormous. Of these, the role of mangroves in mitigating the large-scale hydrometeorological disasters is typically important considering the existing vulnerability of the region. The Indian Ocean Tsunami in 2004 which claimed the lives of more than 230,000 people in fourteen countries particularly marked the importance of coastal mangroves. Following the Tsunami, Kathiresan and Rajendran (2005) reported that the presence of mangrove directly correlated with less number of losses of human lives [35]. Similar conclusive arguments have also been referred by several researchers from different countries in this region, where it was observed that mangroves have shielded the coastal communities from typhoon, cyclones, and a number of other coastal hazards. Extreme events such as Tsunami may be an unfamiliar event in the region; however, degraded and fragmented mangroves increased the disaster loss to several extents. At present, the entire Myanmar coast remains at stake due to its high potential for a giant earthquake and subsequent Tsunami in the Bay of Bengal [36]; also, many South and Southeast Asian countries have already faced the adverse impact of climate change. With sea level rise and increase in ocean water temperature, it is likely that tropical cyclones will become more intense in future along with higher precipitation [37]. Therefore, it is highly imperative to reorganize the perceptions about mangrove and provide them a fair chance to grow and protect the vulnerable coastlines.

\section{Factors behind the Degradation of Indo-Malayan Mangroves}

Degradation of the Indo-Malayan mangroves has been a result of continuous developmental pressure exerted on the coastal areas of South and Southeast Asia. In the past, several mangrove forests were annihilated and converted to 
coastal cities. Megacities like Singapore, Jakarta, Bangkok, Manila, Yangon, Kolkata (Calcutta), and Mumbai (Bombay) were built over mangrove forestland. Yet, the loss has been predominantly severe in only the last three decades. At one side, mangrove suffered anthropogenic pressure beyond its ecological threshold; on the other hand, climate change events are also adversely affecting some of the premier mangrove habitats of this region. Climate change components that affect mangroves include changes in sea level, high water events, storms, precipitation, temperature, and oceanic circulation [38]. Cumulative impacts of these factors have a distinct synergy with respect to an accelerated rate of mangrove degradation. However, the delineating factors differ significantly among the diverse mangrove habitats in the Indo-Malayan ecoregion. Table 3 summarizes various factors that are presently adversely affecting different mangrove habitats of Indo-Malayan ecoregion. The following paragraphs describe the impact of various anthropogenic and climatic factors presently persisting on Indo-Malayan mangroves.

4.1. Anthropogenic Factors. In case of South and Southeast Asia, development of coastal agricultural land and shrimp farming ponds in intertidal areas are considered as the major factors behind mangrove delineation. Of these, conversion of mangrove forest for agriculture is typically prominent in countries like India, Bangladesh, Myanmar, Thailand, and Indonesia. Giri et al. (2008) reported that agricultural activities in the mentioned countries are responsible for nearly $82 \%$ of the reported loss during 1975-2005 [39]. Agriculture is also the major livelihood of several coastal communities inhibiting the large deltas of this region. As a result, mangrove forest in Ganga-Brahmaputra-Meghna Delta in India and Bangladesh and Ayeyarwady delta in Myanmar are amongst the worst sufferer due to agricultural land conversion. In the Sundarban mangroves, more than 150000 ha of mangroves were diverted for agricultural land during the past 100 years [40]. Similarly, in the Ayeyarwady delta in Myanmar, rice cultivation accounted for almost $24 \%$ (55873 ha) reduction of mangrove forest during 1954 to 1984, and following the next decade, the conversion rate has escalated by threefold [41].

Shrimp cultivation is the second largest anthropogenic cause of mangrove deforestation in South and Southeast Asia. The process of shrimp farming is economically lucrative for the coastal communities. Particularly, with huge demands of commercially produced shrimp in the western countries, it ensures high economic return. $75 \%$ of the global commercial shrimps are produced in Asia, and Thailand remains the single largest exporter of commercially produced shrimps. In the late eighties, skeptic rise in global price of commercially produced shrimps prompted South and Southeast Asian governments to support this traditional practice which in turn took the shape of an unsustainable polluting industry. The process destroyed nearly $50 \%$ of Thai mangroves [42]. In a recent satellite-based observation, it has been estimated that since 1975 , approximately $41 \%$ (18816 ha) of Thailand mangroves, 63\% (20956 ha) of Indonesian mangrove, 22\% (7554 ha) of Indian mangrove, and 11\% (1070 ha) of the Bangladeshi mangroves were diverted to shrimp ponds [39].
The Mekong delta mangroves also lost approximately $50 \%$ of their habitat due to shrimp cultivation.

Apart from these two major delineating factors, the South and Southeast Asian mangroves are presently experiencing huge population growth and rapid coastal infrastructure development and urbanization in its vicinity. Even though only $2 \%$ of mangrove forests were diverted for establishment of new coastal settlements in this region [39], yet the problem persists with the observed coastward migration. On the other hand, coastal infrastructure development in terms of port and harbors is strongly associated with mangrove degradation. Port Qasim at Karachi (Pakistan) and Port Mundra in Gujarat, India, are largely criticized of degrading the vulnerable Indus delta mangroves. In the eastern coast of India, Paradip port was built over dense patches of Mahanadi delta mangroves [43]. Similar instances are found to occur in Malacca strait (Malaysia), where mangrove habitats were deforested for building up ports (Port Klang and Malacca port), industrial states (Penang), and commercial centers (Malacca and Penang) [44]. One of the important consequences of this development is severe marine pollution unsustainable for the growth of the mangroves. Marine pollution, particularly oil spillage along the coast, has resulted in further loss of mangroves in this region. Mangroves are highly susceptible to oil exposure, and it may kill them within a few weeks to several months [45]. The collision of Panamanian vessels off the Mumbai coast in late 2010 resulted in oil spill of over 800 tonnes in the Arabian seas, with a reported loss 1273 hectares of reclaimed mangroves. Similar instances are also available from the Gulf of Malacca, in Malaysian coast, which serves as an international corridor for cargo vessels. At least 18 reported oil spill incidents were recorded at the Gulf of Malacca; reportedly damaging the coastal mangroves. Lastly, the Indo-Malayan mangroves also experienced the ill effects of armed conflicts. It was reported that at least $1000 \mathrm{sq} \cdot \mathrm{km}$ of mangroves were destroyed during the Vietnam War by the widespread use of defoliating herbicide mixtures named as Agent Orange.

4.2. Environmental and Natural Factors. Mangroves show exceptional morphological and physiological adaptation skills to counter the environmental and natural stress associated with their intertidal habitat. Yet, tampering of upstream environment and climate change events has contributed significant alteration of the mangrove habitats. Geoclimatically, the Indo-Malayan mangroves now face a more challenging environment for their continual survival. Among the environmental or natural degrading factors of mangroves, rising sea level, increased salinity, and reduction of freshwater flow are considered to be most crucial. Three major South and Southeast Asian rivers, namely, the Indus, Ganges, and the Mekong are listed among the top ten rivers of the world with substantial reduction of flow [46]. As a consequence, deltaic mangroves of these rivers remain at a stake from considerable rise in water and soil salinity. In the past, salinity adversely affected the species diversity of mangroves. It is reported that species diversity in the Indus River Delta mangroves has virtually reduced to only one (Avicennia marina) owing to extreme saline conditions resulting from 


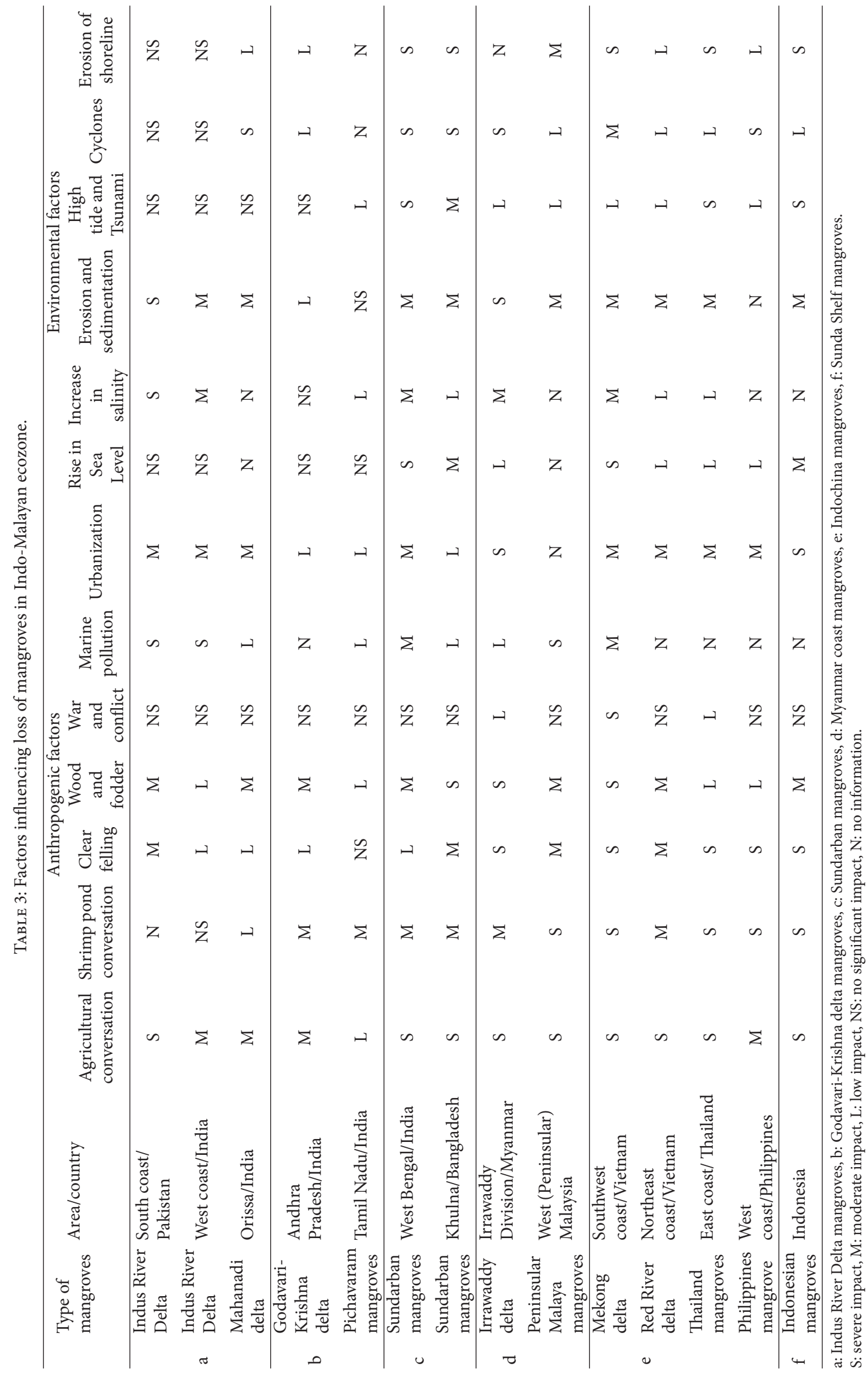


more than $90 \%$ reduction in freshwater flow. Similarly, widespread occurrence of the "top dying" disease of mangroves in Sundarbans is now considered to be an impact of salinity rise due to significant reduction in freshwater flow.

Among the other environmental factors, coastal dynamics and sea level rise play an important role in degrading the mangroves. Erosion loss and submergence under the rising sea are widespread along the eastern coast of India, eastern and southern coast of Thailand, southern coast of Vietnam, and northern coast of Indonesia. In recent past, several islands of Sundarban mangroves both in India and Bangladesh suffered from severe erosion and inundation due to the rising sea level in the Bay of Bengal. Lohachara Island in the Indian Sundarbans is considered to be the first island to be permanently inundated by the rising sea. An assessment carried out during 2001-2002 showed that out of the remaining 100 islands of Indian Sundarbans, 12 are very much prone to coastal erosion and high-tide events [47]. On the other hand, a recent remote sensing based observation revealed that some $53 \mathrm{sq} \cdot \mathrm{km}$ of mangrove forests were affected in the eastern coast of Thailand while $43 \mathrm{sq} \cdot \mathrm{km}$ of mangroves were lost in the western coast as a result of erosion. The present rate of coastal erosion in Thailand ranges from 0.04 to $0.13 \mathrm{sq} \cdot \mathrm{km} / \mathrm{y}$ in the west and east coast, respectively [48]. Mangroves along the western coast of the Peninsular Malaysia are also getting eroded away by the sea. Similar instances can be drawn from Indonesia, where a number of known mangrove patches have been degraded or eroded away. Erosion is severe in the coast of Java islands and other provinces such as Lampung, Northeast Sumatra, Kalimantan, West Sumatra (Padang), Nusa Tenggara, Papua, South Sulawesi, and Bali. On the contrary, Irrawaddy delta mangroves in Myanmar are presently affected by increased sedimentation and coastal accretion. It is interesting that deposition in coastal areas may cause a decrease in the tidal prism in rivers running through the mangrove, resulting in the closing of tidal creeks and the degradation of the forest [49]. Sedimentation rate of the Irrawaddy is the fifth highest in the world. This is largely because of the deforestation that has occurred throughout central Myanmar. The quantity of alluvial deposit is so immense that delta extends further and further into the Bay of Bengal each year resulting in natural thinning of the mangrove forests. Similarly, the Segara Anakan Lagoon of the Central Java of Indonesia lost its complete mangrove habitat due to high sedimentation.

In addition, loss of mangrove habitats due to natural disasters is typically prominent in South and Southeast Asia. Over the past, Indo-Malayan mangroves were subjected to several hydrometeorological disasters of great magnitudes. The mangroves have shielded the coastal communities; however, in turn, it absorbed huge losses. Following the Orissa Super Cyclone in 1999, Forest Survey of India assessed that at least $50 \%$ and $40 \%$ mangrove forests were lost in the two districts of Orissa (Jagatsinghpur and Kendrapara) which had significant share of the Mahanadi mangroves. Similarly, cyclonic storm "Sidr" in 2007 destroyed some 30000 ha of Sundarban mangrove forests. The Myanmar coast also lost sizable mangrove forest following the Cyclone "Nargis" in
2008. Yet, the Indo-Malayan mangroves had the worst possible impact from Indian Ocean Tsunami in 2004. Indonesia, Thailand, Sri Lanka, and India lost considerable amount of mangroves in this event; however, it was reported that the extent of mangrove damage could not be assessed thoroughly due to the large-scale massacre of lives and property [3]. Rough estimations of mangrove loss in Indonesia revealed that almost 25000 ha of mangroves were damaged; however, Indonesian government later revealed that only 300-750 ha of mangroves were lost in the Aceh Province of Sumatra $[3,50]$. In India, as per the damage assessment report of Forest Survey of India, the devastation of mangroves was greatly limited to the Nicobar Islands in the Andaman Sea. However, some reports informed that Pichavaram mangroves suffered $5-10 \%$ damage due to the Tsunami. In case of Thailand, reported loss of mangroves was about 306 ha [50].

\section{Management of Mangrove Ecosystems in South and Southeast Asia}

South and Southeast Asia spans over several postconflict states and some of the world's poorest countries. Many South and Southeast Asian countries have lowincome despite economic growth in recent decades. Most importantly, coastal areas of these countries are immensely populated, and the mangroves are surrounded by a larger proportion of economically deprived coastal communities. Hence, traditional livelihood dependence on mangroves and an exponential population growth forms a formidable challenge in managing the mangroves. Of late, recent developmental pressure adds woes to it. Yet, since the last decade, some progress has been made in successful conservation and restoration of mangroves. In the South and Southeast Asian region, conservation and restoration of mangroves largely revolve around initiatives and actions made by the federal or provincial governments. Although, previously many governments considered the mangroves as "wasteland" and overlooked their ecological and environmental values in developmental planning, some dense mangrove patches along the South and Southeast Asian coast are presently assigned to a certain level of legislative protection. On the other hand, sustainable forest management (SFM) is also being practiced in some mangrove areas; however, such examples are extremely limited. Diagrammatic representation of key concern and management challenges is presented in Figure 2.

5.1. Legislative Protection of Mangroves. Legislative protection of mangroves comes from the idea of in-situ conservation under the "protected area" concept. Although approximately $25 \%$ of the global mangroves are presently conserved under varied degree of protection, in case of the IndoMalayan ecoregion, rough estimation reveals that less than $20 \%$ of the mangroves presently possess such status. Yet, evidence of mangrove conservation in the region can be documented since the colonial era, especially under the Forest Conservation Act, 1927 of British India. Under this particular act, approximately 344870 ha of mangrove forests were transferred to Sindh Forest Department for effective conservation which still forms one of the largest protected 


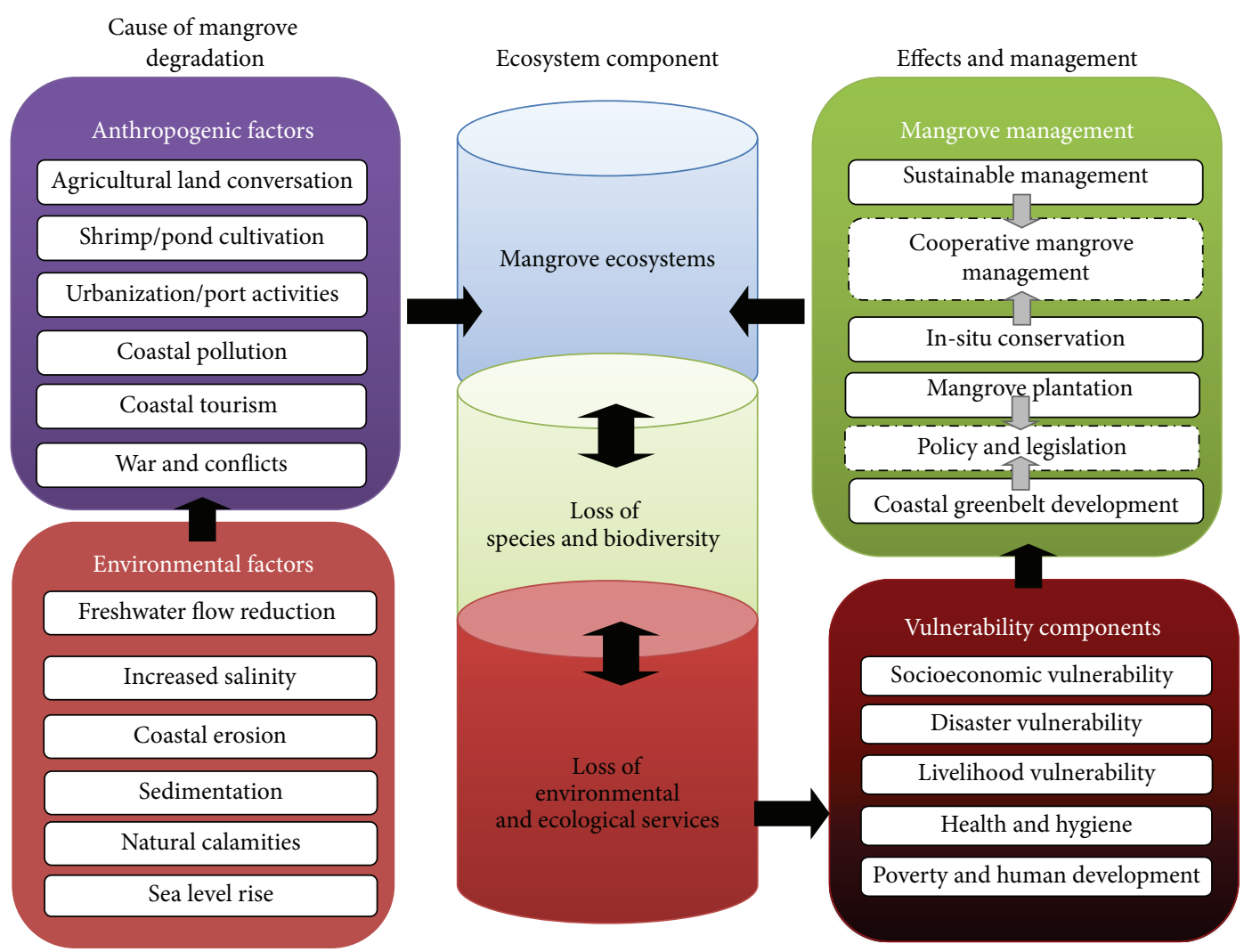

FIgURE 2: Schematic diagram of mangrove degradation and its restoration strategies in South and Southeast Asia.

mangrove areas in Pakistan [51]. Similarly, this act was also instrumental for the protection of Sundarban mangroves both in India and Bangladesh. Nevertheless, legislative protection of mangroves was predominantly ratified after the Ramsar Convention (1971) on "the Wetlands of International Importance." Two specific measures suggested in the Ramsar Convention were "conservation" and "wise use of wetland resources." Although initially only 11 Asian countries joined this convention, it strongly initiated the need of mangrove conservation into the national policies of several South and Southeast Asian Countries. Following the convention, Pakistan, India, Philippines, and Indonesia formed National Mangrove Management Committee to promote mangrove conservation. Presently, all the South and Southeast Asian countries with dense to moderate mangroves have joined the convention with the latest addition of Myanmar in 2005. Of late, following the Indian Ocean Tsunami, several countries have mentioned mangrove restoration as a national priority. Also, some of them ratified the "coastal green belt" concept which involved massive mangrove plantation along the coast. For example, about 12000 ha of mangroves were planted by the Vietnamese government only as coastal protection initiatives. On the other hand, Government of Bangladesh initiated massive plantation program of 120,000 ha following the Cyclone "Sidr." However, despite the legislative protection and massive plantation, poor implementation of laws and by laws largely proved conservation efforts futile in almost all the South and Southeast Asian countries. Coastal communities invaded the mangroves for their continual survival, and as a result, conservation and plantation initiatives could only result in conflicts among the local governments and mangrove-dependent communities. On the other hand, a new set of environmental worries from massive water pollution and unsustainable development of coastal areas escalated mangrove deforestation. Many countries formed a second set of legislation that indirectly controls the mangrove degradation. Yet, the problem persisted with poor level of implementation and inadequate monitoring framework. In this paper, a comparative analysis in terms of existing country-specific legislative arrangements for mangrove is produced in Table 4.

5.2. Sustainable Management of Mangroves and Comanagement Initiatives. Sustainable Forest Management is a key concept that uses the forests in a way, and at a rate, that maintains their biodiversity, productivity, and the regeneration capacity. It essentially allows traditional uses of forest in a regulated way, so that the ecosystem services are not hampered. Although the formal definition of Sustainable Forest Management came after the United Nations Conference on Environment and Development (UNCED) in 1992, Sustainable Mangrove Management can easily be referred to the advocacy of Ramsar Convention about the "wiseuse" of wetlands. In case of Indo-Malayan mangroves, Sustainable Mangrove Management (SMM) is still a less used tool as the countries lack political will and institutional transparency. Yet, the best example of Sustainable Mangrove Management can also be referred from this ecoregion. The Matang mangrove forest, 

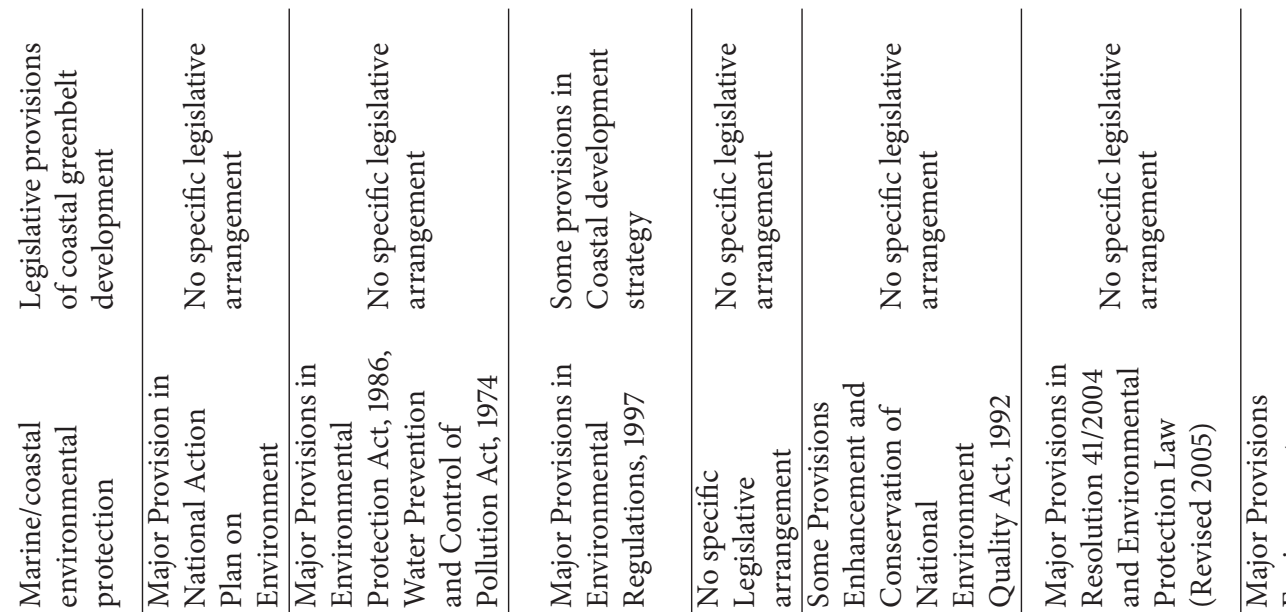

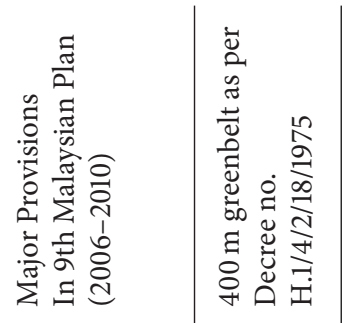

¿

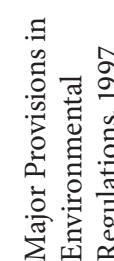

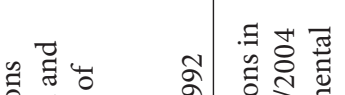

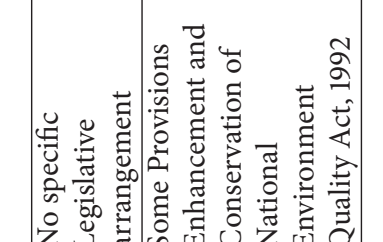

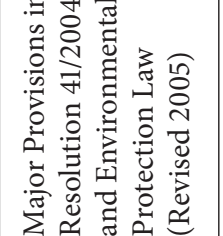

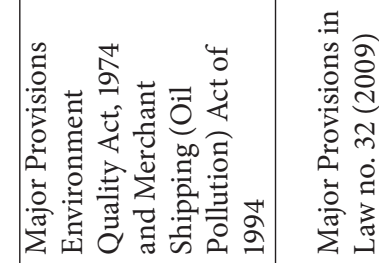

传

है

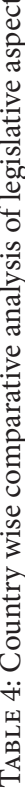

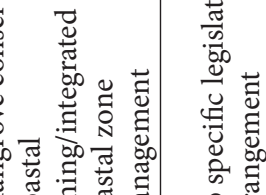

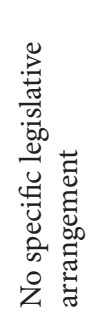

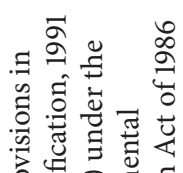

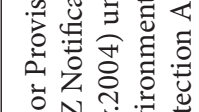

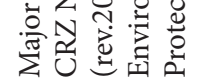

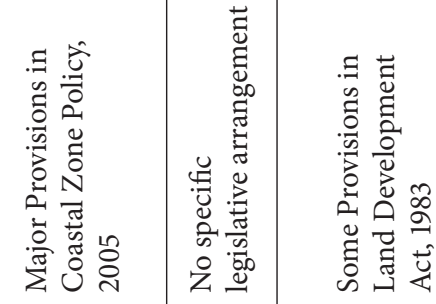

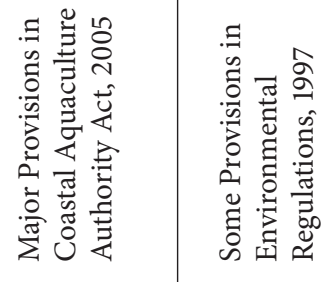

(1)

自

品

-

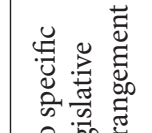

央密

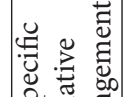

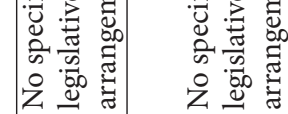

$\exists \quad$ च

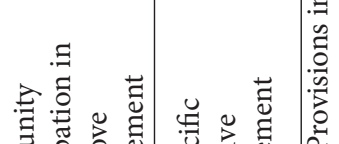

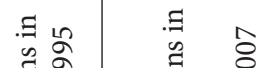

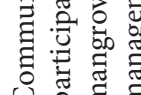

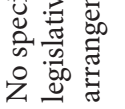

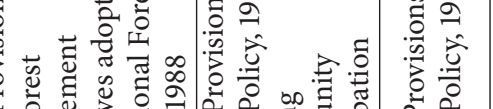

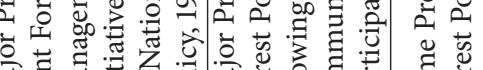

บ $\Xi$

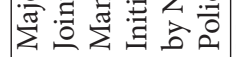

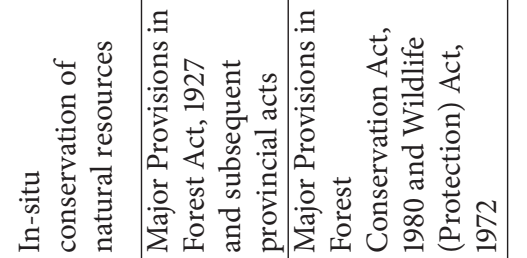

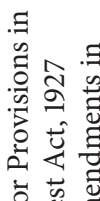

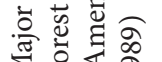

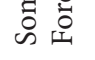

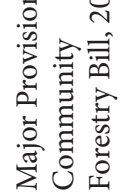

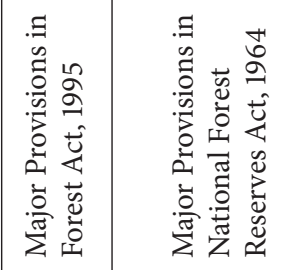

크

:0ّ

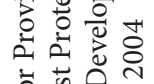

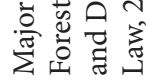

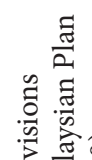

空

蒙吉亮

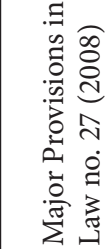

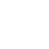

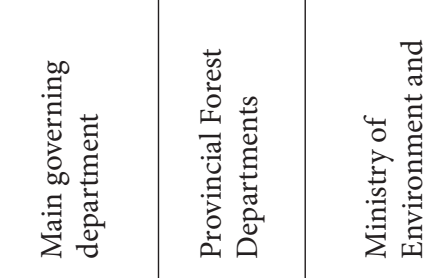

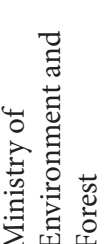

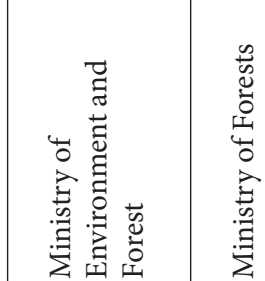

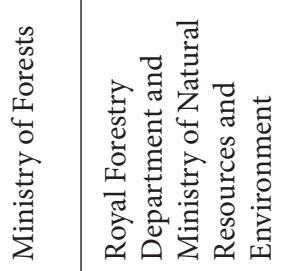

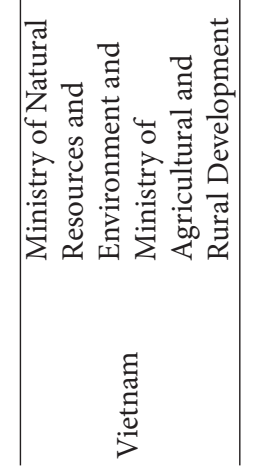

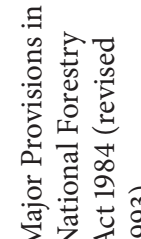

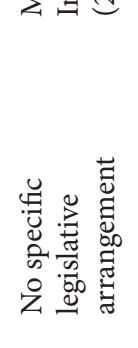

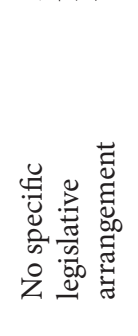

:

点氙念

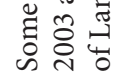




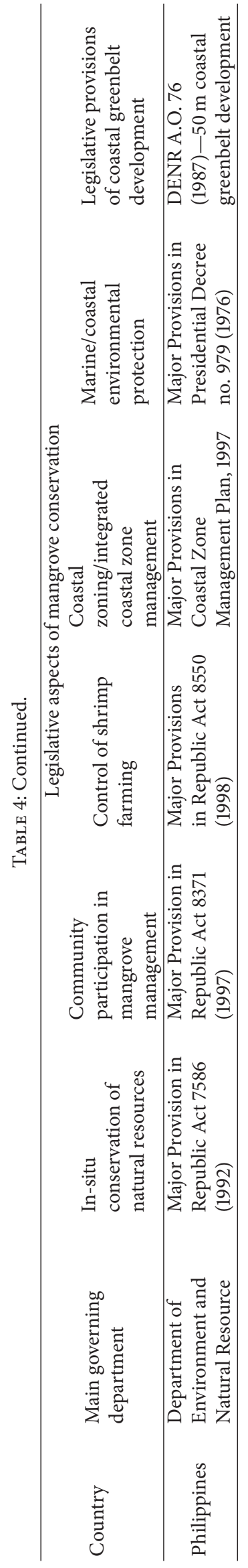


covering some 4000 ha in the peninsular Malaysia, is a classic example of sustainable management of mangroves. The forest is managed over hundred years through the active participation of all stakeholders. Almost $75 \%$ of this forest is designated as productive forest and exploited for wood resources, while the rest are conserved for promoting biodiversity. The 30-year rotation cycle of mangrove felling gives the highest net return on capital value. At present, the timber industry from Matang supports almost 2400 people and earns revenue of USD 6 million. The unproductive forest, on the other hand, supports about 10000 people with gross annual revenue of USD 12-30 million through sustainable fishing practices [52].

Sustainable Forest Management originates from the key concept of comanagement of forest resources and essentially involves multiple stakeholders. In South and Southeast Asian countries, mangrove-dwelling communities have long been ignored in the centralized mangrove management policies. As a consequence, conservation initiatives could not achieve the desired results. Since late eighties, many countries in the region shifted towards a decentralized management approach involving the local communities as an important stakeholder. Since the last decade, community-based mangrove management (CBMM) has gained popularity in almost all the South and Southeast Asian countries. CBMM is particularly prominent in Indo-Malayan ecoregion, yet the level of its penetration varies significantly. In the Indo-Malayan ecoregion, the present success of mangrove restoration as well as conservation largely depends upon the community participation in mangrove restoration and management. CBMM initiatives are particularly prominent in Thailand, Indonesia, Philippines, Bangladesh, and India. One of the finest examples of CBMM is regarded as the restoration of the Pichavaram mangrove forest in India. Pichavaram is the second largest mangrove forest in India; however, owing to over exploitation of aquatic resources and persisting natural calamities, it was degraded to a great extent. As per the remote sensing evidence of 1986 , about $25 \%$ of the Pichavaram mangrove was found critically degraded. However, the entire mangrove habitat was restored by the local fishing communities with the intermediation of a leading NGO $[13,53]$. Although clear felling is now restricted in Pichavaram, reclaimed mangroves proved essential in restoration of livelihood concerns of large fishing communities.

Many countries have modified or presently are modifying the existing mangrove management framework to accommodate CBMM initiative which is by and large turned out to be the most successful mangrove management model in this region. In case of Thailand, it is mentioned by the Royal Government that a greater number of successful CBMM initiatives helped to maintain the desirable nationwide mangrove cover of more than $2000 \mathrm{sq} \cdot \mathrm{km}$. [54] However, CBMM initiatives are still in a nascent stage in several countries of South and Southeast Asia. In countries like Vietnam and Malaysia, CBMM has been adopted; yet, its effectiveness is still not proved beyond doubt. In case of Vietnam, CBMM is initiated under Protection Forest Management Boards (PFMBs) at provincial level, but it neither contains any legal sanctity nor extends the forest rights to the managing communities [55]. Also, it is reported that poor incentive does not essentially interest the community in comanagement initiatives. Yet, CBMM has tremendous potential, especially in countries like Pakistan and Myanmar, where loss of livelihood due to mangrove deterioration adversely affected the coastal communities.

\section{Recommended Strategies and Way Forward}

In this study, it has been observed that irrespective of climate change and persisting natural calamities, anthropogenic interventions are the root causes of the degradation of IndoMalayan mangroves. Two specific human activities in form of coastal agriculture and shrimp farming have also been highlighted as major depleting factors of the South and Southeast Asian mangroves. It is also observed that the loss of mangroves has been strongly associated with the increasing disaster vulnerability of the coastal communities. Hence, it is highly imperative to form a full proof, sustainable, and comprehensive mangrove management strategy for the revival as well as conservation of Indo-Malayan mangroves. Therefore, a set of recommended strategies has been provided in order to continue the valuable ecosystem and environmental services of the Indo-Malayan mangroves. The recommended strategies are broadly categorized under three sections.

\section{Restructuring of Legislative Framework}

(i) South and Southeast Asian countries exhibit tremendous potential of community-based mangrove management (CBMM); however, in many countries, it lacks legal sanctity. Also, it was observed that even though communities are involved, they procure only the secondary role in mangrove management. Hence, it is highly imperative to mainstream CBMM into national mangrove management strategies and empower the local community in decision making process. Better economic incentives are also crucial in terms of economic sustainability of CBMM approaches. At present, CBMM approaches should be legalized, and necessary amendments should be made in all legislative aspects of mangrove management in order to avoid contradictions.

(ii) The existing legislative arrangements for mangrove conservation are not yet full proof and also contradictory in nature. In one hand, many local governments promote aquaculture in coastal areas; on the contrary, mangrove conservation is also simultaneously prioritized. Therefore, more transparent legislative framework is envisaged. Although countries like India and Bangladesh are typically strong on the policy front, implementation and monitoring mechanism is essentially poor in all the South and Southeast Asian countries. Therefore, protective legislations need to include comprehensive monitoring mechanisms at all levels of governments. All the countries should conduct management audit at central, provincial, and local level. 
(iii) On the other hand, secondary legislative arrangements for mangrove management need to be strengthened. It is observed that despite the huge loss of mangroves due to shrimp farming, most of the countries in this region do not own a suitable legislation for control of shrimp farming in mangrove areas. As a result, virgin mangrove areas are regularly encroached for illegal shrimp farming. Therefore, it is essential for countries like Thailand, Malaysia, and Indonesia to formulate and implement proper legislation for control of shrimp farming in mangrove areas.

(iv) Coastal zoning and integrated coastal zone management (ICZM) approach is another very important aspect of mangrove management. Although some countries have already formulated legislative framework for coastal zoning; meticulous implementation of the prescribed guidelines is strongly required. Countries like Pakistan, Myanmar, and Vietnam need to strengthen their legislative arrangements for coastal zoning in order to promote sustainable development along the coasts.

\section{Governance and Institutional Dimension of Mangrove Management}

(i) In all the South and Southeast Asian countries, multiple government agencies/departments manage different components of the mangrove resources. Although forest departments of federal or provincial governments hold the key responsibility, several other government departments are critically associated with mangrove management, especially, in resource assessment and harvesting, economic valuation, and community development. The civil government is largely responsible for community empowerment. In the past, poor coordination among the various government departments led to mismanagement of mangroves. Therefore, increased coordination among the managing authorities is strongly envisaged. Also, it is recommended to form a central agency that can coordinate the entire management activities through a "bottom up" approach.

(ii) Institutional capacities of the local government officials need to be improved with proper scientific training. In many restoration initiatives in this region, lack of knowledge in species and site selection resulted in low survival and ineffective restoration. Even if the mangroves were restored, the ecosystem services could not be streamlined. In general, plantation activities should include the broader perspective of ecosystem restoration.

\section{Balanced Economic Development and Transboundary Cooperation}

(i) Economic development in coastal areas needs to be done in a sustainable way with proper care of the mangroves. Although provisions of environmental impact assessment for developmental activities are prevalent in almost all the South and Southeast Asian countries, their significance is constantly challenged against the economical and developmental priorities. Special emphasis is therefore required for careful selection of developmental sites. Also, compensatory aforestation should be promoted for developmental activities in mangrove areas.

(ii) Finally, regional cooperation for transboundary ecosystem management needs to be enhanced. Out of the six mangrove habitats in the Indo-Malayan ecozone, five are shared by two or more nations. Therefore, regional cooperation for joint action plan, joint monitoring program for ecosystem health assessment, and transboundary environmental management form crucial management issues. Presently, some formal initiatives are in place in Sundarban mangroves between India and Bangladesh; however, given the extent of mangrove extent of Indo-Malayan ecoregion, it is highly recommended for a regional platform to share different management experiences, opportunities, and challenges.

\section{Acknowledgment}

The first author greatly acknowledges MEXT (MONBUKAGAKUSHO) scholarship provided by the Japanese Government for conducting research in the Graduate School of Global Environmental Studies of Kyoto University.

\section{References}

[1] N. C. Duke, J. O. Meynecke, S. Dittmann et al., "A world without mangroves?” Science, vol. 317, no. 5834, pp. 41-42, 2007.

[2] D. M. Alongi, "Present state and future of the world's mangrove forests," Environmental Conservation, vol. 29, no. 3, pp. 331-349, 2002.

[3] D. M. Alongi, "Mangrove forests: resilience, protection from tsunamis, and responses to global climate change," Estuarine, Coastal and Shelf Science, vol. 76, no. 1, pp. 1-13, 2008.

[4] M. Spalding, M. Kainuma, and L. Collins, World Atlas of Mangroves, Earthscan, London, UK, 2010.

[5] B. A. Polidoro, K. E. Carpenter, L. Collins, N. C. Duke, A. M. Ellison et al., "The loss of species: mangrove extinction risk and geographic areas of global concern," PLOS ONE, vol. 5, no. 4, article e10095, 2010.

[6] C. Giri, E. Ochieng, L. L. Tieszen et al., "Status and distribution of mangrove forests of the world using earth observation satellite data," Global Ecology and Biogeography, vol. 20, no. 1, pp. 154-159, 2011.

[7] World Wide Fund for Nature (WWF), "World Eco-region," 2013, http://worldwildlife.org/biomes/.

[8] "Global species database," 2013, http://www.globalspecies.org/ .

[9] S. M. Saifulla, Management of Indus Delta Mangroves in Coastal Zone Management Imperative for Maritime Developing Nations, Kluwer Academic Publications, Norwell, MA , USA, 1997.

[10] A. Shah, I. Kasawani, and J. Kamaruzaman, "Degradation of indus delta mangroves in Pakistan," International Journal of Geology, vol. 1, no. 3, pp. 27-34, 2007. 
[11] MSSRF, Atlas of Mangrove Wetlands of India, Swaminathan Research Foundation, Chennai, India, 2004.

[12] K. Kathiresan, "A review of studies on Pichavaram mangrove, southeast India," Hydrobiologia, vol. 430, no. 1-3, pp. 185-205, 2000.

[13] MSSRF, Joint Mangrove Management in Tamil Nadu: Process, Experiences and Prospects, Part 1: Situation Analysis: Pichavaram and Muthupet Mangrove Wetlands, Swaminathan Research Foundation, Chennai, India, 2003.

[14] V. Selvam, "Environmental classification of mangrove wetlands of India," Current Science, vol. 84, no. 6, pp. 757-765, 2003.

[15] B. Gopal and M. Chauhan, "Biodiversity and its conservation in the Sundarban mangrove ecosystem," Aquatic Sciences, vol. 68, no. 3, pp. 338-354, 2006.

[16] Instituto Oikos and BANCA, Myanmar Protected Areas, Context, Current Status and Challenges, Ancora Libri, Mialno, Italy, 2011.

[17] FAO, Global Forest Resources Assessment 2005: Thematic Study on Mangroves, Myanmar, 2005.

[18] F. Blasco and M. Aizpuru, "Mangroves along the coastal stretch of the Bay of Bengal: present status," Indian Journal of Marine Sciences, vol. 31, no. 1, pp. 9-20, 2002.

[19] K. Jusoff, "Managing sustainable mangrove forests in peninsular Malaysia," Journal of Sustainable Development, vol. 1, no. 1, pp. 84-96, 2008.

[20] FAO, The World's Mangrove 1980-2005, Food and Agriculture Organization, 2007.

[21] M. Vannuchi, Indo West Pacific Mangroves in Mangrove Ecosystems: Functions and Management, Springer, New York, USA, 2001.

[22] I. C. Campbell, The Mekong-Biophysical Environment of An International River Basin, Elsevier, New York, NY, USA, 2009.

[23] J. B. Long and C. Giri, "Mapping the Philippines' mangrove forests using Landsat imagery," Sensors, vol. 11, no. 3, pp. 2972-2981, 2011.

[24] Sabah Forest Department, "Mangrove forest management and its restoration in Annual Report," 2007.

[25] S. Abbas, F. M. Qamer, N. Hussain, R. Saleem, and K. T. Nitin, "National level assessments of mangrove forest cover in Pakistan," in Workshop Proceedings: Earth Observation for Terrestrial Ecosystem, pp. 187-192, 2011.

[26] "State Forest Report," Government of India, Ministry of Environment \& Forests, 2011.

[27] Bangladesh Forest Department, "National Forest and Tree Resources," Assessment Report 2005-2007, 2008.

[28] FAO, "Global Forest Resources Assessment," Country ReportMyanmar, 2010.

[29] Bakosurtanal, "National survey \& mapping coordination agency, indonesia: peta mangrove Indonesia," Indonesian Mangrove Atlas, 2009.

[30] Government of Vietnam, Decision No. 1267/QD-BNN-KL, National Statistics on Forest Land, 2008.

[31] J. E. Padilla, "Analysis of coastal and marine resources: a contribution to the Philippine," Report Submitted to the World Bank, 2008.

[32] MFF, Thailand, National Strategy Action Plan, 2011-2013, 2011.

[33] A. A. Memon, "Devastation of the indus river delta," in Proceedings of the World Water and Environmental Resources Congress, Anchorage, Alaska, USA, May 2005.
[34] E. B. Barbier, Mangrove Dependency and the Livelihoods of Coastal Communities in Thailand in Environment and Livelihoods in Tropical Coastal Zones, CAB International, 2006.

[35] K. Kathiresan and N. Rajendran, "Coastal mangrove forests mitigated tsunami," Estuarine, Coastal and Shelf Science, vol. 65, no. 3, pp. 601-606, 2005.

[36] P. R. Cummins, "The potential for giant tsunamigenic earthquakes in the northern Bay of Bengal," Nature, vol. 449, no. 6, pp. 75-78, 2007.

[37] UNESCAP and ISDR, The Asia Pacific Disaster Report, 2010.

[38] E. L. Gilman, J. Ellison, N. C. Duke, and C. Field, "Threats to mangroves from climate change and adaptation options: a review," Aquatic Botany, vol. 89, no. 2, pp. 237-250, 2008.

[39] C. Giri, Z. Zhu, L. L. Tieszen, A. Singh, S. Gillette, and J. A. Kelmelis, "Mangrove forest distributions and dynamics (19752005) of the tsunami-affected region of Asia," Journal of Biogeography, vol. 35, no. 3, pp. 519-528, 2008.

[40] K. Kathiresan, "Threats to Mangroves in Training Course on Mangroves and Biodiversity," United Nations University, 2011, http://ocw.unu.edu/international-networkon-water-environment-and-health/unu-inweh-course-1-mangroves/Course_listing/.

[41] O. N. Win, "Present state and problems of mangrove management in Myanmar," Trees, vol. 16, no. 2-3, pp. 218-223, 2002.

[42] E. Barbier and M. Cox, "Economic and demographic factors affecting mangrove loss in the coastal provinces of Thailand, 1979-1996," Ambio, vol. 31, no. 4, pp. 351-357, 2002.

[43] P. K. Nanda, "The port of Paradip: mangrove forest to a major port," in Orissa Review, pp. 68-78, Government of Orissa, 2011.

[44] I. B. H. Omar, "National report of Malaysia on the formulation of a trans-boundary diagnostic analysis and preliminary framework of a strategic action program for the bay of bengal," Tech. Rep., United Nations Environment Program, 2002.

[45] NOAA [National Ocean Atmospheric Administration], Oil Spills in Mangroves: Planning and Response Considerations, United State Department of Commerce, 2002.

[46] WWF, "World's top ten rivers at Risk," Tech. Rep., 2007.

[47] WWF, "Sundarban future imperfect: climate adaptation report," Tech. Rep., 2010.

[48] U. Thampanya, J. E. Vermaat, S. Sinsakul, and N. Panapitukkul, "Coastal erosion and mangrove progradation of Southern Thailand," Estuarine, Coastal and Shelf Science, vol. 68, no. 1, pp. 75-85, 2006.

[49] B. Brown, "Resilience thinking applied to the mangroves of Indonesia," in IUCN \& Mangrove Action Project, Yogyakarta, Indonesia, 2007.

[50] EJF, "Nature's defence against Tsunamis: a report on the impact of mangrove loss and shrimp farm development on coastal defence," in Mangroves, Environmental Justice Foundation, London, UK, 2006.

[51] I. Mukhtar and A. Hannan, "Constraints on mangrove forests and conservation project in Pakistan," Journal of Coastal Conservation, vol. 16, pp. 51-62, 2012.

[52] M. T. C. [Malaysian Timber Council], "Matang Mangroves: a century of sustainable mangment," Timber Malaysia, vol. 15, no. 3, pp. 7-11, 2009.

[53] Y. Ogino, R. Shaw, and R. R. Krishnamurthy, Community Perspective of Mangrove Protection and its Implication to Coastal Zone Management in Pichavaram, South India in Communities and Coastal Zone Management, Research Publishing Services, 2010. 
[54] D. Datta, R. N. Chattopadhyay, and P. Guha, "Community based mangrove management: a review on status and sustainability," Journal of Environmental Management, vol. 107, pp. 84-95, 2012.

[55] MFF, Vietnam, National Strategy and Action Plan, 2011-2013, 2011. 

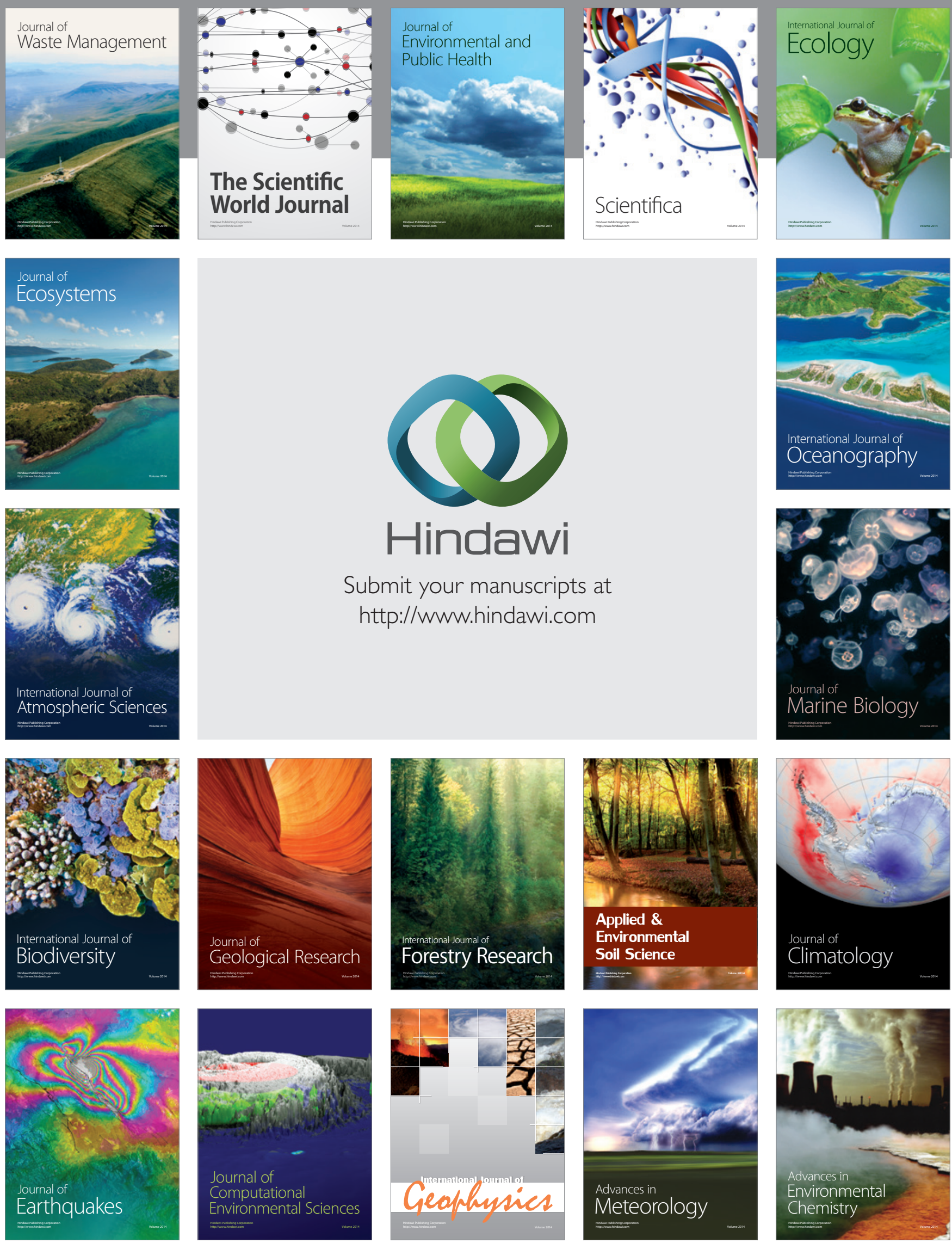